probably accelerated the fatal course in one of them. 'The same cause might explain the outcome in other cases of fatal side effects of valproate. ${ }^{1}$ The families of such children need to be investigated because $(a)$ a common cause of fatal valproate toxicity might be found, $(b)$ a procedure to detect people at risk might be advised-for example, measuring plasma ammonia concentrations for initial monitoring of treatment-and $(c)$ confidence about using the drug for children and adults without a metabolic abnormality might be restored.

1 Rolles $\mathrm{CJ}$. Hepatic injury with sodium valproate:a reappraisal with special reference to children. $\mathrm{Br}$ f Clin Pract 1983;27(suppl):72-6.

2 Warter JM, Brandt C, Marescaux C, et al. The renal origin of sodium valproate-induced hyperammonaemia in fasting humans. Neurology (Cleveland) 1983;33:1136-40.

3 Geiseler D, Kay JDS, Oberholzer VG, et al. Determination of the rate of urea synthesis from serial measurements of urea concentration after an alanine load: theoretical and methodological aspects. Clin Sci 1985;68:201-8.

4 Harris ML, Oberholzer VG. Conditions affecting the colorimetry of orotic acid and orotidine in urine. Clin Chem 1980;26:473-9.

5 Kay JDS, Geiseler D, Oberholzeı VG, et al. Systems analysis of the synthesis of urea following an alanine load in normal subjects and patients with ornithine transcarbamoylase deficiency. In Third international symposium on inborn errors of metabolism in humans. Basle: Karger 1984:86.

(Accepted 18 September 1985)

Department of Clinical Biochemistry, Hospitals for Sick Children and Institute of Child Health, London WC1N 3JH

M HJELM, MD, FRCPATH, professor and honorary consultant

L V K DE SILVA, MB, MRCPATH, lecturer and honorary senior registrar

J W T SEAKINS, MA, PHD, senior lecturer

V G OBERHOLZER, BA, top grade biochemist

Department of Paediatrics, Southampton General Hospital, Southampton SO9 4XY

C J ROLLES, FRCP, consultant paediatrician

Correspondence to: Professor Hjelm.

\section{Apheresis in the management of loiasis with high microfilariaemia and renal disease}

Membranous glomerulopathy is sometimes associated with loiasis, ${ }^{1.3}$ a common disease in western and central Africa. We describe a case in which renal symptoms improved after treatment of loiasis with apheresis followed by diethylcarbamazine.

\section{Case report}

A 28 year old man, who had been born in Cameroon but had lived in France from 1976, presented with recurring episodes of itching. Loiasis was diagnosed with microfilariaemia of $35 \times 10^{6} /$. The eosinophil count was $1 \cdot 6 \times 10^{9} / 1$. Stools and urine were negative for parasites; results of serological tests were negative for syphilis, hepatitis B surface antigen, and schistosomas and positive for filarias and malaria. Serum creatinine concentration was $122 \mu \mathrm{mol} / \mathrm{l}(1.4 \mathrm{mg} / 100 \mathrm{ml})$. Urine

Effects of three successive sessions of apheresis on microfilariaemia

\begin{tabular}{lcc}
\hline & \multicolumn{2}{c}{ Microfilaria count $\left(\times 10^{6} / 1\right)$} \\
\cline { 2 - 3 } & Before apheresis & After apheresis \\
\hline Day 1 & $30 \cdot 1$ & $22 \cdot 3$ \\
Day 2 & $26 \cdot 1$ & $15 \cdot 5$ \\
Day 3 & $16 \cdot 8$ & $7 \cdot 1$ \\
\hline
\end{tabular}

contained albumin $(2.8 \mathrm{~g} / 24 \mathrm{~h})$ and red blood cells $\left(25 \times 10^{3} / \mathrm{min}\right)$ but no leucocytes. Serum complement concentrations (C3, C4) were in the normal range. Renal biopsy showed membranous glomerulitis with microfilarias in the glomerules and the vessels as described in other cases ${ }^{12}$; immunofluorescence microscopy showed $\operatorname{IgG}, \operatorname{IgM}$, and C3 in a diffusely granular pattern without $\mathrm{IgA}$. To avoid massive lysis of microfilarias the microfilariaemia was reduced by apheresis (Haemonetics V50 blood processor, Hemonetics, Massachussets, USA) before treatment with diethylcarbamazine. The standard procedure for collection of platelets was followed by centrifugation at $4800 \mathrm{rpm}$. About $3 \cdot 2$ litres of blood were processed in seven cycles during each session of apheresis. Three session were performed on consecutive days at midday, when the microfilariaemia was highest. The table shows effect of the three sessions on the number of microfilarias in the blood. About $2.8 \times 10^{8}$ microfilarias were extracted during the three sessions. This procedure was well tolerated with the platelet count falling from 383 to $140 \times 10^{9}$ platelets $/ 1$.

$\mathrm{He}$ was then treated with diethylcarbamazine, starting with low doses $(5 \mathrm{mg} /$ day $)$ that were progressively increased; prednisolone $(0.5 \mathrm{mg} / \mathrm{kg} /$ day $)$ was added for the first few days. Transient moderate itching occurred. After 15 days of treatment (diethylcarbamazine $400 \mathrm{mg} /$ day) no microfilarias were detectable. After nine months (diethylcarbamazine $100 \mathrm{mg} /$ day) microfilarias remained undetectable, the haematuria had cleared, and proteinuria ranged between 0.4 and $1.0 \mathrm{~g} / 24 \mathrm{~h}$. Serum creatinine concentration was $114 \mu \mathrm{mol} / 1(1.3 \mathrm{mg} / 100 \mathrm{ml})$.

\section{Comment}

In loiasis with high microfilariaemia diethylcarbamazine may be responsible for serious side effects such as encephalitis ${ }^{45}$ due to the lysis of microfilarias, and the risks of treatment can be more important than the risks associated with the disease. Loiasis with visceral complications such as renal or cardiac conditions, however, should be treated. In our patient the loiasis was treated because it was considered to be the cause of the membranous glomerulopathy and we hoped to relieve the renal symptoms. Glomerulopathy associated with loiasis is believed to be immunologically mediated ${ }^{1-3}$; massive lysis of microfilarias at the start of treatment with diethylcarbamazine induces an antigen overload that could worsen renal symptoms, and so the microfilariaemia should be reduced before specific chemotherapy. In 1983 Muylle et al first reported the success of apheresis in reducing microfilariaemia in two cases, ${ }^{5}$ showing that microfilarias are concentrated in the buffy , oat by discontinuous flow centrifugation and can be extracted with a blood cell separator. To our knowledge this technique has never been used in patients with loiasis and renal disease. In this case, with a follow up of nine months, we observed an improvement in urinary sediment and stabilisation of renal function. Further observations are warranted to confirm the benefit of specific treatment for renal symptoms in the management of such patients.

1 Bariety J, Barbier M, Laigre MC, et al. Protéinurie et loase. Etude histologique, optique et électronique d'une cas. Bulletins et Mémoires de la Société Médicale des Hôpitaux de Paris 1967;118:1015-25

2 Pillay VKG, Kirch E, Kurtzman NA. Glomerulopathy associated with filarial loiasis. fAMA 1973;225:179.

3 Katner H, Beyt BE Jr, Krotoski WA. Loiasis and renal failure. South Med $\mathcal{J}$ 1984;77:907-8.

4 Fain A. Les problèmes actuels de la loase. Bull WHO 1978;56:155-67.

5 Muylle L, Taelman H, Moldenhauer R, Van Brabant R, Peetermans M. Usefulness of apheresis to extract microfilarias in management of loiasis. BrMed f 1983;287:519-20.

Accepted 21 August 1985)

Service de Médecine Interne, Hôpital Louis Mourier, 92700 Colombes, France

L ABEL, MD

V JOLY, MD

$P$ YENI, MD

C CARBON, MD, chief of service

Centre de Secteur d'Hémobiologie-Transfusion, Hôpital Saint Louis, 75475

Paris Cedex 10, France

A BUSSEL, MD

Correspondence and requests for reprints to: Dr P Yeni, Hôpital Bichat, 75877 Paris Cedex 18.

\section{Renal artery occlusion in patients with renovascular hypertension treated with captopril}

In patients with renal artery stenosis reversible renal failure of the kidney on the affected side may occur during treatment with captopril. We describe three patients with atherosclerotic renal artery stenosis who developed occlusion of the affected renal artery during treatment with captopril while awaiting percutaneous transluminal angioplasty. This was preceded by long term treatment with captopril (13-21 weeks), which is said to guide prediction of curability.

\section{Case reports}

Case 1-A 62 year old man after 10 years of severe hypertension $(235 / 135 \mathrm{~mm}$ $\mathrm{Hg}$ ) seemed to have $75-90 \%$ stencsis of the left and minimal stenosis of the right renal artery. Renal function was unimpaired (plasma creatinine concentration 89 $\mu \mathrm{mol} / 1(1.01 \mathrm{mg} / 100 \mathrm{ml})$, creatinine clearance $100 \mathrm{ml} / \mathrm{min}$ ) (table). Treatment 
Intervals between arteriography, start of treatment with captopril, and diagnosis of occlusion of renal arteries in three patients with renovascular hypertension. Plasma creatinine concentrations were measured at beginning and end of indicated periods

\begin{tabular}{|c|c|c|c|c|c|c|c|}
\hline \multirow[b]{2}{*}{ Case No } & \multirow[b]{2}{*}{ Age (years) } & \multirow[b]{2}{*}{ Sex } & \multirow[b]{2}{*}{$\begin{array}{c}\text { Stenosis } \\
(\%)\end{array}$} & \multicolumn{2}{|c|}{$\begin{array}{l}\text { Arteriography to start } \\
\text { of treatment with captopril }\end{array}$} & \multicolumn{2}{|c|}{$\begin{array}{l}\text { Start of treatment with captopril to } \\
\text { occlusion of renal artery }\end{array}$} \\
\hline & & & & $\begin{array}{l}\text { Intervals } \\
\text { (weeks) }\end{array}$ & $\begin{array}{l}\text { Plasma creatinine } \\
(\mu \mathrm{mol} / \mathrm{l})\end{array}$ & $\begin{array}{l}\text { Intervals } \\
\text { (weeks) }\end{array}$ & $\begin{array}{l}\text { Plasma creatinine } \\
\qquad(\mu \mathrm{mol} / \mathrm{l})\end{array}$ \\
\hline 1 & 62 & $M$ & $75-90$ & 1 & $89-89$ & 13 & $89-120$ \\
\hline 2 & 64 & $M$ & $75-90$ & 12 & $201-208$ & 13 & $208-270$ \\
\hline 3 & 51 & $M$ & $>90$ & 16 & $122-127$ & 21 & $127-148$ \\
\hline
\end{tabular}

Conversion: SI to traditional units-Creatinine: $1 \mu \mathrm{mol} / \mathrm{l} \approx 0.01 \mathrm{mg} / 100 \mathrm{ml}$.

with captopril, chlorthalidone, and atenolol ( 13 weeks) decreased blood pressure to $155 / 88 \mathrm{~mm} \mathrm{Hg}$ and increased plasma creatinine concentration to $120 \mu \mathrm{mol} / \mathrm{l}$ $(1.41 \mathrm{mg} / 100 \mathrm{ml})$. Arteriography, performed immediately before percutaneous transluminal angioplasty, showed the left renal artery completely occluded.

Case 2-A 64 year old man with recent hypertension $(210 / 126 \mathrm{~mm} \mathrm{Hg})$ seemed to have $75-90 \%$ stenosis of the left renal artery. Treatment with captopril and chlorthalidone (13 weeks) decreased blood pressure to 178/96 mm $\mathrm{Hg}$. Renal function was slightly impaired before treatment began (creatinine clearance 77 $\mathrm{ml} / \mathrm{min})$. Plasma creatinine concentration rose from 200 to $270 \mu \mathrm{mol} / \mathrm{l}(2 \cdot 26$ to $3.05 \mathrm{mg} / 100 \mathrm{ml}$ ) during treatment. Arteriography before percutaneous transluminal angioplasty showed the left renal artery completely occluded after treatment.

Case 3-A 51 year old man after two years of hypertension $(170 / 110 \mathrm{~mm} \mathrm{Hg})$ seemed to have severe stenosis $(>90 \%)$ of the right renal artery and impaired renal function (plasma creatinine concentration $129 \mu \mathrm{mol} / \mathrm{l}(1.46 \mathrm{mg} / 100 \mathrm{ml})$, creatinine clearance $86 \mathrm{ml} / \mathrm{min}$ ). Treatment ( 16 weeks) with metoprolol, hydrochlorothiazide, and amiloride did not affect blood pressure or renal function. Treatment with captopril and chlorthalidone ( 21 weeks) decreased blood pressure (118/84 $\mathrm{mm} \mathrm{Hg}$ ) and increased plasma creatinine concentration to $148 \mu \mathrm{mol} / \mathrm{l}$ $(1.67 \mathrm{mg} / 100 \mathrm{ml})$. We decided to perform percutaneous transluminal angioplasty. Arteriography before this, however, showed a completely occluded right renal artery.

\section{Comment}

It is difficult to prove that treatment with captopril contributed to the occlusion of the severely stenotic renal arteries in these patients, especially as two used $\beta$ blockers, which are also said to provoke renal artery thrombosis. ${ }^{1}$ We do, however, consider that captopril was a precipitating factor because: firstly, intervals were short between arteriography, start of treatment, and diagnosis of renal artery occlusion; secondly, plasma creatinine concentrations increased during treatment but not before it began; and, thirdly, blood pressure responded well to captopril, making it less probable that rapid progress of the atherosclerotic lesion because of persisting high blood pressure would have lead to occlusion of the renal arteries.

Reports on renal artery thrombosis during inhibition of angiotensin converting enzyme are scanty, ${ }^{23}$ but inhibitors of angiotensin converting enzyme are thought to provoke renal artery occlusion. ${ }^{3}$ Hollenberg, however, found no renal artery thrombosis in 269 patients treated with captopril. ${ }^{4}$

These are the only such cases known to the manufacturers of captopril (personal communication, Dr A J Spijker, Squibb Benelux), ${ }^{23}$ and the Netherlands Centre for Monitoring Adverse Drug Reactions has not received any report on renal artery thrombosis and inhibition of angiotensin converting enzyme (personal communication, B H C Stricker).

The blood pressure lowering effect of long term treatment with captopril is said to guide prediction of curability of renovascular hypertension. The experiences in our patients made us and others ${ }^{3}$ reluctant to prescribe inhibitors of angiotensin converting enzyme for more than one month, especially when severe renal artery stenosis is present.

1 Shaw AB, Gopalka SK. Renal artery thrombosis caused by antihypertensive treatment. Br Med $\mathcal{f}$ 1982;285:1617

2 Williams PS, Hendy MS, Ackrill P. Captopril-induced acute renal artery thrombosis and persistent anuria in a patient with documented pre-existing renal artery stenosis and renal failure. Postgrad Med f 1984;60:561-3.

3 Tillman DM, Malatino LS, Cumming AMM, et al. Enalapril in hypertension with renal artery stenosis: long-term follow up and effects on renal function. Fourmal of Hypertension 1984;2(supp 2):93-100

4 Hollenberg NK. Medical therapy of renovascular hypertension: efficacy and safety of captopril in 269 patients. Cardiovascular Reviews and Report 1983;4:852.

(Accepted 25 September 1985)

Division of General Internal Medicine, St Radboud Hospital, 6525 GA Nijmegen, the Netherlands

W H L HOEFNAGELS, MD, consultant internist

T THIEN, MD, consultant internist

\section{Cross infection with Streptococcus pneumoniae through a Resuscitaire}

Transmission of Streptococcus pneumoniae between members of the same family and between patients in the same ward has been reported. ${ }^{1-3} \mathrm{We}$ report here the transmission of $S$ pneumoniae type 6 between two infants resuscitated consecutively with the same piece of equipment (Resuscitaire) 48 hours apart.

\section{Case reports}

A 31 year old woman was admitted in labour with ruptured membranes. Caesarean section was performed after a prolonged and difficult labour and fetal distress. The baby was asphyxiated at birth with an Apgar score of 3 at one minute and 9 at five minutes, thus requiring immediate intubation and resuscitation. Despite ventilation and a high dosage regimen $(50 \mathrm{mg} / \mathrm{kg}$ every eight hours) of benzyl penicillin and gentamicin $(2 \cdot 5 \mathrm{mg} / \mathrm{kg}$ every 12 hours) the baby died after eight hours.

A gastric aspirate taken at birth yielded $S$ pneumoniae type 6 . At necropsy severe bronchopneumonia was found and $S$ pneumoniae type 6 was isolated from the bronchi and lung tissue. Twenty four hours after delivery the mother was

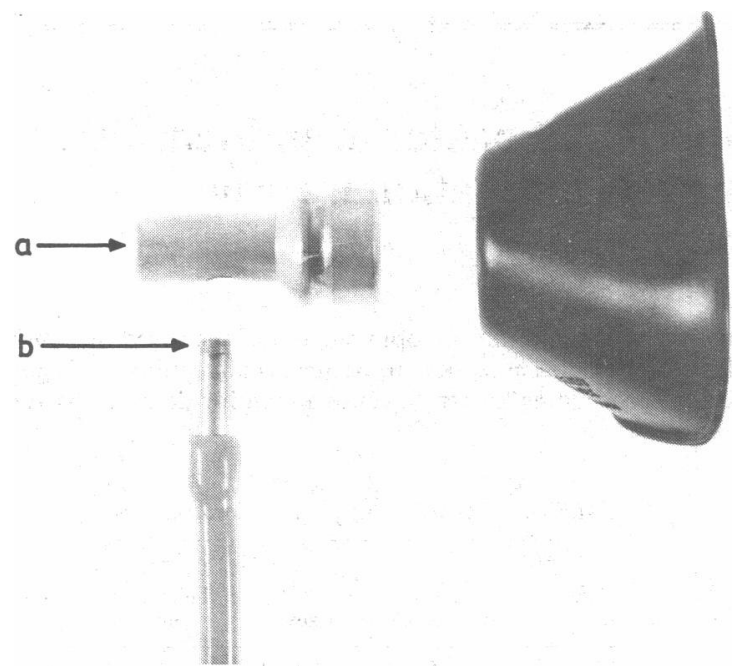

Resuscitaire and its components, including $\mathrm{T}$ piece connector $(a)$ and thread of $T$ piece $(b)$.

clinically unwell. A high vaginal swab and midstream specimen of urine yielded $S$ pneumoniae type 6 . She then developed a wound infection 48 hours postoperatively from which $S$ pneumoniae type 6 was also isolated. She was treated with parenteral benzylpenicillin $2 \mathrm{MU}$ every six hours for six days, made a satisfactory recovery, and was discharged. Follow up high vaginal swab specimens yielded negative results.

Forty eight hours after the first infant had been resuscitated a second baby born by caesarean section required intubation and ventilation for fetal distress. After 12 hours this infant developed signs of infection, and a gastric aspirate taken at birth grew $S$ pneumoniae type 6 . High dose penicillin and gentamicin were started immediately after birth, and the baby gradually improved and made an uneventful recovery. The second mother was screened for pneumococci, but no pathogens were isolated.

Extensive investigations were carried out, including bacteriological screening of all attending staff, equipment in the labour ward, and the environment. It was found that these two babies had been ventilated consecutively on the same Resuscitaire. In the interval between these two births three infants had been born 